HoST - Journal of History of Science and Technology

Vol. 14, no. 2, December 2020, pp. 73-93

10.2478/host-2020-0015

\title{
The Perfect Pair: Bloch, Febvre, and the History of Science and Technology
}

\author{
Maria Paula Diogo \\ Centro Interuniversitário de História das Ciências e da Tecnologia (CIUHCT) \\ Faculdade de Ciências e Tecnologia, Universidade NOVA de Lisboa \\ mpd@fct.unl.pt
}

\begin{abstract}
Launched in 1929 by Marc Bloch and Lucien Febvre, the Annales gave rise to a groundbreaking approach to history known as the École des Annales. Based on the study of social history over a long-term period or longue durée, the new paradigm emphasized the collective nature of the mentalités and the importance of a multilayered analysis of society. The Annales reclaim the history of science and the history of technology as part of history as a whole and inextricably linked to the intellectual context of a specific time period. In this article, based on the Annales and UNESCO's History of Mankind, I will focus on Bloch's and Febvre's stands on history and their relevance to the history of science and technology, particularly by championing the relevance of material and mental tools to understand each historical moment and by critically exploring the concepts of mentalités, histoire-problème, histoire totale and historical temporality.
\end{abstract}

Keywords: Annales; Febvre; Bloch; history of science and technology; historical temporality 


\section{Combat and Praise for History: The Birth of the Annales d'Histoire Économique et Sociale}

In just nine years from now the first issue of the Annales d'Histoire Economique et Sociale will celebrate its one hundredth anniversary. The French journal launched by Marc Léopold Benjamin Bloch (1886-1944) and Lucien Paul Victor Febvre (1878-1856) on 15 January 1929 gave rise to the groundbreaking approach to history known as the École des Annales (Annales School). In a very concise first editorial of the new journal - "A nos lecteurs" ("To our readers")—, Bloch and Febvre claimed that their main goal as editors was to create an interdisciplinary forum for dialogue among researchers from different disciplines-history, anthropology, sociology, geography, economy-, all united by the same sacrosanct principle of writing honest, rigorous and conscientious narratives. ${ }^{2}$

One might have expected a detailed presentation of the École des Annales' programmatic agenda in the first editorial of the journal, but not a single word was written by Bloch and Febvre on the topic. Both editors argued that the innovative approach of the journal should become clear by the actual contents of the articles and not by theoretical statements. This is very much the case, as across its different phases-Annales d'histoire économique et sociale (1929-1939), Annales d'histoire sociale (1939-1942, 1945), Mélanges d'histoire sociale (19421944), Annales. Economies, sociétés, civilisations (1946-1994), and Annales. Histoire, Sciences Sociales (1994-) — a new approach to history was put in place by taking all dimensions of society into consideration (not only the traditional political, military and diplomatic levels) and emphasizing the collective nature of mentalities. This is particularly clear in the reviews authored by Bloch and Febvre on the books published both in and outside of France, which were scrutinized and fiercely criticized in the light of the Annales' agenda.

The rationale behind the École des Annales was nevertheless explicitly presented by its founders in two major books: the Apologie pour l'histoire ou Métier d'historien (The Historian's Craft) ${ }^{3}$ by Bloch and Combats pour l'histoire by Febvre (Fighting for History). In both cases, the authors presented the design of a new historiography anchored on the study of long-term historical structures (longue durée), often using quantification (as, after all, economic history was at the

\footnotetext{
1 This article was, in fact, written in 2019, on the occasion of the ninetieth anniversary of the Annales.

2 On the École des Annales, see André Burguière, "Histoire d'une histoire: la naissance des Annales," Annales. Économies, Sociétés, Civilisations 34, no. 6 (1979): 1347-1359; Jacques Revel, "Histoire et Sciences Sociales: Les Paradigmes des Annales," Annales. Histoire, Sciences Sociales 34, no. 6 (1979): 1360-1376; Peter Burke, The French Historical Revolution: The Annales School 1929-2014, 2nd rev. ed. (Cambridge: Polity Press/John Wiley \& Sons, 2015).

3 Marc Bloch, The Historian's Craft (Manchester: Manchester University Press, 2006). Originally published as Apologie pour l'histoire ou métier d'historien (Paris: Armand Colin, 1949). Page references are to the 2006 edition.
} 
core of the Annales) and paying special attention to intellectual and cultural worldviews of specific periods and places. The Annales chose to focus its attention on the mental frameworks that shaped decisions and practices rather than on events, biographies or political or warinduced transformations and on historical patterns identified in social, economic and cultural history. Despite having very different personalities and styles of writing and not always agreeing on the decisions to be made at critical moments, Bloch's and Febvre's works manage to establish a dialogue which, being conceptually and methodologically coherent, functions as a reverberation box that amplifies the Annales's programmatic agenda. In this sense, Bloch and Febvre are a "perfect pair."

The Annales came to life in troubled times. In the aftermath of World War I, the crash of economy—deflation, recession and unemployment—on a worldwide scale (striking America and Europe in one hit) shifted the gaze from political to economic issues. The 1920s were dominated by debates on economic decisions: Lenine's NEP (Novaya Ekonomicheskaya Politika) (New Economic Policy), Poincarés restoration of the gold standard for the franc, Roosevelt's New Deal. In this context, in which politicians were increasingly judged by their economic successes or failures, it is only natural that economic topics became dominant in many circles, including in the academic world. Not surprisingly, these were times of revolt, particularly among the young generation of intellectuals whose main mission was to be provocatively against the status quo.

On the other hand, within the academic milieu the Annales were influenced by different approaches that challenged traditional views and disciplinary boundaries: (i) the geography of Pierre Vidal de La Blache, a historian who became a geographer and who aimed at shaping geography as the science of the present time centered on permanent features such as places, landscapes, visible effects on the earth's surface and various natural and human phenomena; (ii) the Revue de synthèse historique (Historical Synthesis Journal) launched in 1900 by Henri Berr who, although with no historical background, but a literary and philosophical one, considered history as the science of sciences and championed a new kind of history that took into account all dimensions of reality; (iii) the L'Année Sociologique (The Sociological Year) and Emile Durkheim's influence, which, although certainly conflictual, was inspirational to both Bloch 
and Febvre who were able to use the Durkheimian method while avoiding its major pitfalls, namely concerning the diversity of causes that explain social phenomena and the individual agency. ${ }^{4}$

Although there is a mythology of marginality and peripheralization associated to Bloch and Febvre- they taught at the University of Strasbourg, away from the Parisian Sorbonne-they were far from being the outcasts of the French intellectual community both by birth and training. Febvre and Bloch came from a long line of teachers (parents and grandparents) and were brought up in educated families; both studied at the École Normale Supérieure (ENS) ("ont fait Ulm"5), passed the thèse d'Etat (habilitation thesis) and became professors at the university.

On the other hand, the University of Strasbourg that was restored to France in 1920 as a result of the reconquest of Alsace, was a model university set to be a showcase of French excellence versus German culture in Alsace. ${ }^{6}$ Strasbourg was therefore, not a second rate university, but the second ranking university, after Paris, due to the importance of its professors. A significant number of French influential intellectuals were teachers at the university and came to collaborate in the Annales, such as the sociologists Maurice Halbwachs (who was member of the Annales d'histoire économique et sociale's editorial board) and Gabriel Le Bras, the psychologist Charles Blondel, the historians André Piganiol, Charles-Edmond Perrin and Georges Lefebvre. Also, from an epistemological perspective, Strasbourg encouraged interdisciplinarity and pushed the boundaries of sciences, social sciences and humanities, supported by an excellent library and generous funding.

\footnotetext{
${ }^{4}$ For Durkheim a given social phenomena is explained exclusively in terms of factors of the same specific order. In opposition to that, Bloch and Febvre used different civilizational plans in their explanation of the social structure, resorting to both sporadic and profound causes and linking phenomena of different orders. On the other hand, and building on the previous divergence, for Durkheim, in view of the social fact, the action of the individual fades way (the individual and society as a whole belong to different layers, so they cannot be used together to explain reality); for Bloch and Febvre, on the contrary, social facts are explained to the extent that they result from individual actions. For a more extensive analysis on this topic see Susan Friedman, Marc Bloch, Sociology and Geography: encountering changing disciplines (Cambridge: Cambridge University Press, 1996).

${ }^{5}$ This is an expression used extensively in Bloch's and Febvre's biographies and it is commonly used in French to identify the students of the ENS. The ENS is located at the Rue d' Ulm, no 45 (44-48 for the laboratories) in a neighborhood that also hosts the Panthéon, the Sorbonne, the Lycée Louis-leGrand, the Collège de France, the Conservatoire National des Arts et Métiers and, until 1976, the École Polytechnique.

6 The University of Strasbourg is rooted in a Lutheran German Gymnasium founded in 1538. It became a royal university in 1631. During the French Revolution, Alsace became part of the French territory and the university turned into a French-speaking university. After the Franco-Prussian war and the annexation of Alsace-Lorraine to Germany, it was re-founded in 1872 as the Kaiser-WilhelmUniversität and most Francophone teachers had to flee. During the German Empire, the university expanded greatly, becoming a symbol of German culture. In 1918, when Alsace-Lorraine was returned to France, a reverse process took place with the exodus of Germanophone teachers.
} 
This particular status of the University of Strasbourg was eloquently epitomized in 1925 by its Dean, Christian Pfister, when he proudly described his university as the antechamber of Sorbonne, in a way closer to Paris than to the local Alsatian realities. Understandably, the teachers of the University of Strasbourg aspired to move to the capital and succeed at the Sorbonne, which was the case of Febvre and Bloch: Febvre entered in 1933 into the Collège de France and Bloch became, in 1936, professor of economic history at the Sorbonne.

In Strasbourg, Bloch and Febvre, worked in adjoined offices in the premises of the Institut d'Histoire du Moyen-Âge (Institute of Medieval History) and of the Institut d'Histoire Moderne (Institute of Modern History) and it is said that the doors separating the two were always open. They had different personalities_-Bloch was more comfortable in the writing than in the talking and was quite shy, thus seeming sometimes cold and distant; Febvre was a talented speaker and pedagogue who easily touched his listeners-, but both were already well-known in 1929. Febvre had written two noteworthy books, his thesis on Philippe II et la Franche-Comté. Etude d'histoire politique, religieuse et sociale (Philip II and Franche-Comté. A study on political, religious and social history) $(1911)^{7}$ and Un Destin: Martin Luther (A destiny: Martin Luther) $(1928)^{8}$ and was member of the editorial board of the journal Revue d' Histoire Moderne et Contemporaine (Journal of Modern and Contemporary History); Bloch had authored Les Rois thaumaturges (The Royal Touch) (1924). ${ }^{9}$ These books already contained the seeds of the Annales' perspective on history.

In 1928, Bloch was invited to lecture at the Instituttet for Sammenlignende Kulturforskning (Institute for Comparative Research in Human Culture) in Oslo. Here, in his lecture entitled Towards a Comparative History of Europe, he first expounded publicly his theories on total and comparative history, making a strong plea for breaking out of national barriers that circumscribed historical research. ${ }^{10}$ In the same year, Febvre sent Armand Colin his project (that he had designed shortly after the end of World War I) to edit an innovative journal linked to economic history, proposing as title Economic Evolution; Critical Review of Economic and Social History. This time, the plea was for breaking disciplinary boundaries and fostering a unified social science able to respond to the challenges of the present.

\footnotetext{
${ }^{7}$ Lucien Febvre, Philippe II et la Franche-Comté. Étude d'histoire politique, religieuse et sociale (Paris: Honoré Champion, 1911).

${ }^{8}$ Lucien Febvre, Un Destin. Martin Luther (Paris: Rieder, 1928).

9 Marc Bloch, The Royal Touch: Monarchy and Miracles in France and England (Dorset Press, Dorchester: 1990). Originally published as Les Rois thaumaturges (Strasbourg: Presses Universitaires de Strasbourg, 1924).

10 This lecture later resulted in Marc Bloch, Les Caractères Originaux de l'Histoire Rurale Française (Oslo: Instituttet for Sammenlignende Kulturforskning, 1928).
} 
One year later Febvre and Bloch launched the Annales d'Histoire Économique et Sociale. Both editors belonged to a generation trained by Charles-Victor Langlois and Charles Seignobos' Introduction aux Etudes Historiques (Introduction to the Study of History) that defends a methodological approach to history akin to positivism (école méthodique). ${ }^{11}$ As opposed to their masters, they wanted to write a new type of narrative based on the concept of histoireprobleme (history-as-problem), an inclusive tool to end divisions between disciplines. Bloch added a social slant to the more economic-driven agenda of Febvre; the two historians became the directors of the new journal, but invited other scholars to be part of the "adventure": the geographer Albert Demangeon, who served as a precious intermediary with the editor, the sociologist Maurice Halbwachs, the economist Charles Rist, the politologist André Siegfried and fellow historians André Piganiol for the antiquity, George Espinas for the medieval period, Henri Hauser for the modern period (sixteenth to eighteenth centuries), and the Belgian Henri Pirenne, a longtime critic of Langlois' and Seignobos' historical method.

Febvre and Bloch brought together, under the Annales' epistemological umbrella, scholars from different fields, united in a common rejection of an event-based narrative (histoire événementielle). The journal provided a proactive space for discussing an alternative way of writing history, by taking an approach, which rejected the predominant emphasis on politics, diplomacy and war. The reviews — sometimes ferocious — and the texts written for the journal's section Débats et Combats (Debates and Combats), were springboards to feed the controversies and to strengthen the reputation of the Annales as the new historiographical trend. They stood for the histoire totale, histoire tout court, histoire-probleme (total history, history tout court, historyas-problem), that is, the study of history as problem using the long-term historical structures (la longue durée), instead of basing it on events and political transformations. Geography, material culture and what later was called mentalités (mentalities), i.e., psychology of the time, became the cornerstone of the Annales' agenda.

One of the main innovations of the Annales' historiographical approach was the matter of time, in the sense that Febvre and Bloch considered that history studies not only the past but also contemporary society, inviting scholars to be inspired by the problems posed at the present time, in which they lived, thought and wrote. For the Annales, the act of questioning the past from the perspective of the present had a heuristic value, as the present guided the research of the past and enriched its knowledge. This justified the defense of a relativistic concept of historical discourse, that is, the belief that each historical moment builds its representation of the past according to what matters most. If the present contributed to a better knowledge of

${ }^{11}$ Charles-Victor Langlois and Charles Seignobos, Introduction aux Études Historiques (Paris: Hachette, 1898). 
the past, concomitantly knowing the past allowed for a better understanding of the present and therefore, resulted in a more effective action. From a methodological perspective, this pastpresent close relationship called for the use of the reverse method, i.e., the historian starts from the present to trace the thread of time back to the societies of the past.

The Annales criticized the fetishism of "fact" among traditional historians and the historians' alleged passivity/objectivity in the face of events in line with Leopold von Ranke's positivism: to tell what really happened (Wie es eigentlich gewesen ist). For the positivist historian, the historical task was reduced to transcribing documents in their own right, with no additional purpose, purporting to remain in the shadow of facts. On the contrary, Bloch and Febvre argued for an active intervention of historians in the light of documents and archives, as it was through the questions nominated that they built their answers. Deprived from the formulation of the problem and the outline of its solution, historians were disempowered and became clerks, not experts. Historians should make choices both in terms of methodology and source, on the basis of present concerns and confront their hypotheses with the collected documents. In a nutshell, "It is the historian who gives birth to history."

For Bloch and Febvre humankind was at the center of historical practice and discourse. The men and women studied by the Annales were average people, perceived in the context of the surrounding society, adapting to new challenges in an ever-changing world. The practice of history was, thus, to explain change, to make it intelligible. In Febvre's words:

History, Science of Man ... never forget it. Science of the perpetual change of human societies, of their unceasing and constant need for readjustment to new conditions of material existence, political, moral, religious, intellectual. History is the science of this negotiated relationship, of the harmony which is established at all times, between the various and synchronic conditions of human existence: material conditions, technical and spiritual conditions. ${ }^{13}$

In this study of the global life of human societies in the longue durée, the mentalités became critical, putting mankind at its center and being essentially concerned with change: Febvre used ethnology and especially psychology to approach the mental universe, while Bloch fed on Durkheimian sociology; Febvre's approach was very much marked by the perception of the individual, while Bloch devoted more time to describing the collective, symbolic practices and unconscious mental representations of the various social groups.

${ }^{12}$ Lucien Febvre, "Avant-Propos" in Charles Morazé, Trois Essais Sur Histoire et Culture (Paris: Armand Colin, 1948), 8.

${ }^{13}$ Febvre, Combats, 31. Unless otherwise noted, all translations are my own. 


\section{Bloch, Febvre and the concept of time}

Although interested both in science and technology as part of the mentalités, Bloch and Febvre dedicated very few texts explicitly to these topics. Surely both were implicitly part of the new approach to history led by the Annales, but not many dedicated articles were written by its two founders. Even so, there are more texts on the history of technology (l'histoire des techniques) than on the history of science, which is easily understandable because of the close relationship between technology and economy.

Why, then, are these few texts relevant for modern-day historians of science and technology and how do they relate to the longue durée and the mentalités that frame the Annales? It is my conviction that by emphasizing the concept of time and historic temporality, they clarify the difference between the historian's approach to science and technology as opposed to that adopted by philosophers, scientists and engineers.

For Bloch and Febvre, time is the plasma of historical intelligibility and history is the study of humankind in the continuous and ever-changing stream of time. ${ }^{14}$ The purpose of the Annales was not to break the links between the past already legitimized and the present that still needed legitimation, but to empower the historical discourse of the political imperatives of the present and to re-articulate the historian's relation to the past. In this context, Bloch and Febvre enlarged and justified the territory of history, explaining why the past was relevant for present times and why contemporaneity was also part of history. In Bloch's words:

With some reason, perhaps, the man of the age of electricity or of the airplane feels himself far removed from his ancestors. With less wisdom, he has been disposed to conclude that they have ceased to influence him. There is also a modernist twist inherent in the engineering mind. Is a mastery of old Volta's ideas about galvanism necessary to run or repair a dynamo? By analogy ... . it is easy to think that an analysis of their antecedents is just useless for the understanding and solving of the great human problems of the moment.

$\cdots$

A high-school teacher, who was very old when I was very young, once told us: "Since 1830, it is no longer history. It is politics." One would no longer say: "since 1830" .. . nor "It is politics." Rather with a respectful air: "It is sociology;" or, with less respect: "It is journalism." Nevertheless, there are many who would gladly repeat that since 1914 , or 1940 , it is no longer history. ${ }^{15}$

\footnotetext{
${ }^{14}$ Bloch, Historian's Craft, 23. The intelligibility of history is a classic question for historians, dating back to Hume and mostly addresses what Benedetto Croce refers to as the difference between the chronicles and the significant narrative, i.e., between what happened and why it happened.

${ }^{15}$ Ibid., 30-31. Translation modified.
} 
Having established the relevance of history, two concepts often used in the history of science and technology were questioned and dissected—origins and precursor-and the common practice of anachronism criticized.

In Apologie pour l'histoire, Bloch dedicated a specific subchapter to the "idol of origins," much following Francis Bacon's Novum Organum (New Organon) (1620), where he argued that historians were obsessed with the formation of something to the detriment of studying the thing itself, often confusing ancestry and explanation. For Bloch, what was important was to understand how ideas flow and interrelate and mostly how they were appropriated in each historical moment: "No historical phenomenon can be fully explained outside the study of its time." ${ }^{17}$

Febvre followed the same line of argument in the analysis of the concept of a "precursor" in his book on the Franciscan monk Rabelais. ${ }^{18}$ His argument unfolded against the thesis that Rabelais was a "precursor of the atheist and freethinkers of the eighteenth-century" and thus against the claim that there were men "ahead of their time." ${ }^{19}$ Lucien Febvre deconstructed this idea by showing that Rabelais's heretical jokes about the Church were in conformity with the reformist spirit of the time. In other words, Rabelais was a man of his time, and could not be an atheist, because this concept was not part of the sixteenth century "mental tools." Febvre's work on Rabelais sought, under the format of a monograph, to find a method that would allow him not only to refute the concept of a "precursor," but to build a conception of historical temporality within which it could no longer play any role.

The concept of a "precursor" implied the idea of time as a chronological and linear order of events, autonomous in relation to individuals and phenomena. Moreover, it indicated that historical time was part of a deterministic course, followed a specific direction, and did not follow a random and contingent one. A precursor is someone able to escape his time and surpass it, announcing to his contemporaries what the future will be. This concept of time opposes Annales's ontological perspective, in which time is the place of the intelligibility of history that is of individual and collective actions. In this context, how could there be a time with a previously defined sense and how could one break away from any specific moment to travel downstream or ahead of his contemporaries? Therefore, the precursor is, in Febvre's words, an individual "whose justification is impossible." 20

\footnotetext{
${ }^{16}$ Ibid., 24-29.

17 Ibid., 29.

${ }_{18}$ Lucien Febvre, The problem of Unbelief in the sixteenth century, the religion of Rabelais (Cambridge, Mass.: Harvard University Press 1982). Originally published as Le Problème de l'incroyance au XVIe siècle. La religion de Rabelais (Paris: Albin Michel, 1942). Page references are to the 1982 edition.

${ }^{19}$ Ibid., 14.

${ }^{20}$ Ibid., 7.
} 
The same epistemological framework shaped Febvre's criticism to anachronism. Anachronism was "the worst of all sins, the sin that cannot be forgiven"21 and that had to be avoided at all costs. Febvre's claims against anachronism are the perfect example of his motto "À chaque civilisation son outillage mental" (Every civilization has its own mental tools). ${ }^{22}$ For Febvre, the accusation of anachronism is not to say that something did not exist at a given time, but to claim, based on the mental tools of that moment, that something could not have existed at that time. Rabelais could not be an atheist because to be one, such a possibility would need to exist and, at that time, it did not. To make his point clearer, Febvre established an extreme analogy: to claim that Rabelais was a non-believer is "in the realm of ideas it is like giving Diogenes an umbrella and Mars a machine gun."23

The analogy is striking and overstated-because it is common sense that in Diogenes' time there were no umbrellas and Mars was never portrayed with a machine gun, just a spear and shield—but it clearly shows the relevance of the Annales' critique of anachronism:

to protect oneself against these formidable anachronisms - the least recognized as such, and yet the most enormous- that mercilessly expose the muskets at the battle of Fornoue or the photography of Marie-Louise Napoléon at Saint Helena, but easily present Rabelais as a free-thinker . . o or Lamarck a Darwinist before the letter: this is my opinion, and the more I think about it, the supreme ideal, the ultimate goal of the historian. ${ }^{24}$

Bringing together the concept of precursor and the practice of anachronism, Febvre argues that the so-called "precursor" does not exist because there is no such thing as being "ahead of one's time"; even exceptional men ("hommes extraordinaires") are part of their epoch, even if they grasp novelty earlier than their contemporaries. To belong to one's time is, thus, in Febvre's and Bloch's narratives, at the methodological core of the Annales.

\section{Bloch's and Febvre's writings in History of Science and Technology}

Febvre's statement in 1932 that "the individual is just what his time and his environment allow him to be" 25 is a foregleam of the relevance the Annales give to History of Science and Technology as part of the histoire totale and the histoire-probleme that approached history as a multilayered problem to be examined and solved. In Febvre's words: "the history of science is

\footnotetext{
${ }^{21}$ Ibid., 5.

${ }^{22}$ Ibid., 157.

23 Ibid., 353.

${ }^{24}$ Febvre, Combats, 333.

25 Ibid., 209.
} 
an integral and fundamental part of this general history of human societies which will one day be history itself." 26

In this context, both Bloch and Febvre mentioned with concern and on multiple occasions the lack of a discipline in France that could be considered history of science and technology: "We have no good stories from the various sciences," "There is no such a thing as a group of historians of science in France," or "History of technology: one of those many disciplines that have yet to be created entirely—or almost entirely." 27

An expert on the medieval period, Bloch's single text on science topics led him to brush along the edge of science, medicine, witchcraft and religion. In Les Rois Thaumaturges, Bloch investigated the belief that the French and English kings possessed a quasi-magical power of curing scrofula, a disease affecting the bones and lymphatic glands, by touching the sick. Although Bloch's work on the history of technology is also quite sparse, he wrote the seminal text on the technology of medieval water mills "Avènement et Conquêtes du Moulin a Eau" (Advent and conquests of the watermill $)^{28}$ an exercise in how to approach a technical object using Annales' framework, and the review "Les 'inventions' médiévales" (Medieval "inventions") ${ }^{29}$ in which he comments from the Annales' perspective the book by the French officer that became an early historian of technology, Richard Lefebvre de Nöettes, on animal power and social structure La Force Motrice Animale à travers les Âges (The animal driving force through ages) (1924). In both texts, Bloch regretted that historians largely continued to overlook the material conditions of history and would easily write that the Middle Ages were a dark age as far as science and technology were concerned.

During the Middle Ages, "except for the invention of gunpowder, the technical realm ... remained largely stationary." This sentence was written less than fifteen years ago. At the time, it was considered scandalous in the eyes of a few rare specialists. ... We now know without a doubt that, at the time, they set out to conquer the great ocean routes, and that European societies had an infinitely superior skill-set to that of the Roman Empire in its decline. ${ }^{30}$

Following in the footsteps of Febvre and the Annales' rationale, Bloch called the reader's attention to the fact that traditional approaches to the political dynamics of feudalism presented the exercise of authority as if it hovered above and beyond material conditions. In contrast,

\footnotetext{
${ }^{26}$ Ibid., 319.

${ }^{27}$ Lucien Febvre, "Réflexions sur l'histoire des techniques," Annales d'histoire économique et sociale T. 7 , no. 36 (Nov. 30, 1935): 531-35, 531.

${ }^{28}$ Marc Bloch, "Avènement et Conquêtes du Moulin à Eau," Annales d'histoire économique et sociale T. 7, no. 36 (1935): 538-63.

${ }^{29}$ Marc Bloch, “Les 'inventions' médiévales," Annales d’histoire économique et sociale T. 7, no. 36 (Nov. 30, 1935): 634-43.

30 Ibid., 634.
} 
Bloch and Febvre argued that there would be nothing to rule if there were no roads, new ways of harnessing horses and oxen, the redesign of the plow and its use together with teams of multiple-oxen/horses, the change from a two-field crop rotation to a three-field crop rotation, new forms of producing iron and new technologies in the mining industry (mainly the use of pumps), the use of new weaving machines (beginning with the spinning wheel), new energy sources (for instance the water mill) and the reorganization of the textile industry (namely the "putting out" system).

This shift, with a strong focus on materiality_ “réclamer une science mieux agrippée au réel" (call for a science that is better grasped by the real world) ${ }^{31}$ — causes a change in perspective in terms of actors, moving from those who usually were the protagonists of historical narrativeskings, aristocrats, decision-makers - to generally ignored ones, such as peasants and artisans. Likewise, it also entails a change concerning the choice and critique of sources and contents, particularly by acknowledging the existence of a substantial collection of texts and objects that remained for a long time outside the historians' scope of research, being considered irrelevant.

When referring to Nöettes' argument of the negative impact of slavery on technological progress in Classical Antiquity, Bloch proposes to enlarge the scope of the relationship between the social and technical dimensions and to turn it upside down, that is to avoid the tone of technological determinism that permeates Nöettes' work and to bring to the forefront social agency. Nöettes supported that slavery was abolished by the new forms of harnessing horses (using the horse collar), expanding on this example to the more general argument that technology was the driving force behind social change. Bloch, on the contrary, called for a multi-causal approach, stressing that, in the case of slavery, this was even more evident as, by the tenth century, when the horse collar was introduced in Europe, slaves did not exist anymore and had been replaced by servants. He continues by arguing that this shift was due to multiple causes, e.g., the military decline of the Roman Empire (no new lands conquered, no slaves), the specific political and social model of the Carolingian Empire and the rules of Catholicism. Once again, Bloch made a strong plea against the concept of a single cause.

As for Febvre, he first approached the history of science in two reviews published in the Revue de Synthèse Historique: "Une science à travers sa bibliographie. Emmanuel de Margerie et la geologie du Jura," (A science through its bibliography. Emmanuel de Margerie and the geology of the Jura) in 1924, and "Un chapitre d'histoire de l'esprit humain. De Linné à Lamarck et à

${ }^{31}$ Ibid., 635. 
Georges Cuvier" (A chapter in the history of the human mind. From Linné to Lamarck and Georges Cuvier) ${ }^{32}$ in 1927.

In the first case, Febvre used Emmanuel de Margerie's work Le Jura ${ }^{33}$ - a bibliographical list in chronological order (and not alphabetical) with short comments and illustrations from a specific scientific domain (geology) and specific region (the Jura) - as an example of what should be done in other areas of knowledge such as medicine, linguistics, and archaeology, in order to create the necessary body of information that would support a much-needed history of the sciences. In the second case, Febvre's review on Henri Daudin's Etudes d'histoire des sciences naturelles (Studies of natural science history) ${ }^{34}$ afforded the opportunity to reaffirm his views on the history of science as part of history as a whole, closely related to the history of technology and particularly to the history of instruments. In this context, both Febvre's comments on the analyses of the controversy that opposed Lamarck and Cuvier are particularly illustrative, being mostly centered on the use of dissection, and his vivid plea for a stronger social dimension"a beautiful chapter on the social history of the natural sciences" 35 - the only efficient tool to avoid anachronisms and correctly place authors and works in their time.

The same arguments were used in a short review of the work by the biologist Maurice Caullery, La science française depuis le XVII siècle (French Science and Its Principal Discoveries Since the Seventeenth Century) $(1933)^{36}$ to fiercely criticize the author's approach based on the so-called great achievements and great men. Febvre resumes his critique of the concept of precursor, of anachronism, of science alienated from society and of the total absence of any relationship between ideas and practices. Again, the question of time-not as chronology but as the plasma in which actors move and live-is at the core of Febvre's argument: he stands for history of science and not for a record of science ("histoire des sciences" vs "historique des sciences" ${ }^{37}$ ). It is, therefore, an epistemic disagreement about time and historical temporality that separates the historians from the philosophers and scientists who write narratives about the past of sciences. Although in a much more appeasing tone, Febvre insisted on these ideas in the short

\footnotetext{
${ }^{32}$ Lucien Febvre, "Une science à travers sa bibliographie. Emmanuel de Margerie et la géologie du Jura," Revue de Synthèse Historique XXXVII, 1924; Lucien Febvre, "Un chapitre d'histoire de l'esprit humain. De Linné à Lamarck et à Georges Cuvier," Revue de Synthèse Historique XLIII, 1927. These two articles were published later on in Febvre, Combats.

33 Emmanuel de Margerie, Le Jura. Première partie, Bibliographie sommaire du Jura français et suisse (orographie, tectonique et morphologie) (Paris: Imprimerie Nationale, 1922).

${ }^{34}$ Henri Daudin, Études d'histoire des sciences naturelles.-I. De Linné à Jussieu: Méthodes de la classification et idée de série en botanique et en zoologie (1740-1790).--II. Cuvier et Lamarck: Les classes zoologiques et l'idée de série animale (1790-1830) (Paris: Alcan, 1926).

35 Febvre, Combats, 336.

36 Lucien Febvre, "A Propos d'un Précis d'Histoire des Sciences: Sciences et Techniques," Annales d'histoire économique et sociale T. 6, no. 30 (1934): 606-07.

37 Ibid., 606.
} 
introduction to the journal Thalès published by the Institut d'Histoire des Sciences et des Techniques (Institute of History of Science and Technology) at the University of Paris and directed by Abel Rey. ${ }^{38}$

In 1935, Les Annales published their first special issue precisely on the History of Technology: Les techniques, l'histoire et la vie (Technology, history and life). ${ }^{39}$ This issue followed a difficult period for the journal (mainly in 1934 and 1935), as its main collaborators-Pirenne (who died in 1935), Lefbvre, Halbwachs - were too busy to ensure the journal was issued regularly, without letup. Bloch, who felt that it was the directors' duty to save the Annales, pressed Febvre to prepare a special issue that came out in November 1935.

The volume is composed of an opening note by Febvre, in which he justifies the special issue and particularly the article by Guilleux de la Roërie on the gouvernail (rudder) as it defends a different perspective from the one by Nöettes ${ }^{40}$. Two articles followed that became points of reference in the field, "Réflexions sur l'Histoire des Techniques" (Reflections on the history of technology) by Febvre and "Avènement et conquêtes du moulin à eau" by Bloch. They are followed by an article on the rudder ("Les transformations du gouvernail" (Rudder transformations) by Roërie) and one on Frederick Taylor ("Frédéric Winslow Taylor: l'optimisme d'un ingénieur" (Frédéric Winslow Taylor: the optimism of an engineer) by Georges Friedmann). In the section Enquêtes (Inquires), Febvre presented the results of an inquiry into village forges in France and in the section Un Débat de Méthode (Debate on Method), criticized the volume on science, technology and Marxism written by Russian scientists ("À la lumière du Marxisme," In the light of Marxism). The last section Technique et Histoire (Technology and History) includes five short articles: Charles Parain's "L'origine des Plantes Cultivées" (The origin of cultivated plants), Jules Sion's "Quelques Problèmes de Transports dans L'antiquité: le Point de Vue d'un Géographe Méditerranéen" (Some transportation problems in antiquity: the viewpoint of a Mediterranean geographer), Louis Lacrocq's "Un Procès en Révision: le Problème de La Croisée d'ogives" (A process under review: the problem of the rib vault), Bloch's "Les 'inventions' Médiévales" and Febvre' "Pour L'histoire des Sciences et des Techniques" (For the history of science and technology), the latter two already mentioned above in this article.

As the title suggests, Febvre's short article (5 pages) proposes to answer an existential questionQu'est-ce que 'faire l'histoire des techniques'?41 (What is 'making the history of technology'?) by proposing a set of three tasks: 1 . To write a technical history of technology; 2 . To evaluate the

\footnotetext{
${ }^{38}$ Lucien Febvre, "Pour l'histoire des sciences et des techniques," Annales d'histoire économique et sociale T. 7, no. 36 (1935): 646-48.

39 "Réflexions sur l'histoire des techniques," special issue, Annales d'histoire économique et sociale T. 7, no. 36 (Nov. 30, 1935).

${ }^{40}$ Lefebvre de Nöettes, De la Marine Antique à la Marine Moderne (Paris: Masson, 1935).

${ }^{41}$ Febvre, "Réflexions," 531.
} 
role of science in advancing technology and the role of technology in advancing science; 3. To place the history of technology as part of history as a whole, that is in its human context. These three methodological assignments were supported by an epistemological stance based on interdisciplinarity and collaborative work and clearly fulfilled the Annales' rationale concerning how to write History. The Réflexions (Reflections) continued to be discussed over and over right up until now, feeding major debates within the history of technology community, as illustrated by the ones on technological determinism, contextualism, and the relationship between science and technology, invention and innovation, technology and culture.

Bloch's long article on the water mill ${ }^{42}$ is a perfect example of how to write about a technical object, following the Annales's social history and long-term framework. Bloch begins by tracing the very simple instruments for grinding the grains up to the time of the technology of the quern and particularly that of the rotary quern, dating it back to the first century $\mathrm{BC}$ in the East Mediterranean; he then analyzes how the new technology of the mill remained in hibernation, that is without any further innovations, until the rise of the new social, political and economic order of the Middle Ages called for new solutions concerning flour milling; finally, Bloch explores the entanglements between water mills, the new profession of miller, war, manorialism and the commons.

Although in this special issue Febvre authored 5 articles (including the opening note) and Bloch only 2, each wrote an article that became a point of reference in the History of Technology: "Réflexions sur l'Histoire des Techniques" (Febvre) and "Avènement et conquêtes du moulin à eau" (Bloch). As was the case with the authors themselves, these two texts together make a perfect pair: Febvre's text presents a general approach to the Annales' perspective on the history of technology, while Bloch's is a case-study that faultlessly exemplifies its doctrine.

\section{Febvre, UNESCO and the History of Science and Technology}

In 1946, Julian Huxley, founding father and first Director of UNESCO, proposed to write a History of Scientific and Cultural Development of Mankind (for short, History of Mankind), aiming to bring together a comprehensive view of the development of culture in the world as a way to consolidate peace in the aftermath of World War II. Huxley, an evolutionary biologist, soon invited his friend biochemist Joseph Needham to be the first head of UNESCO's Natural Sciences Section and to be part of the editorial project. Needham had been, under the Royal Society's direction, the director of the Sino-British Science Co-operation Office and had traveled extensively in China, becoming deeply interested in Chinese culture. He published a

42 Bloch, "Avènement." 
volume on this topic in 1945 and was preparing to enlarge the scope of his book. ${ }^{43}$ They were joined by the Portuguese historian Armando Cortesão, an expert in the history of Portuguese cartography. ${ }^{44}$

The History of Mankind was framed by an evolutionary approach to history and the belief that science was the main tool of progress. Huxley, Needham and Cortesão were supported by the archaeologist Gordon Childe, who wrote a report to be presented at the UNESCO General Conference in Mexico City (1947) subscribing Huxley's agenda. Although the general idea was approved, the delegates asked for a more detailed report concerning practical issues. Soon after, in 1948, Needham left the project, accused by the Americans of being a spy as he was a member of the Cambridge University Communist Group. Huxley and Cortesão continued to work on the sketch of the project, developing a clear evolutionist framework in which the cultures of the world were portrayed and classified as primitive, barbaric, intermediary and advanced.

In the fall of 1948, so as to prepare for the presentation of the History of Mankind at the annual UNESCO Conference in Beirut, Huxley and Cortesão met the highly acclaimed Annales's star Febvre. The clash between Febvre and Huxley was inevitable, as for the French historian the idea of writing a hierarchized world history was unacceptable, as well as the fact that the authors were all European. This initial disagreement became more explicit when, in the aftermath of the Beirut Conference, Febvre was asked to write a report on Huxley's project, following Huxley's replacement as director-general by the Mexican Jaime Torres Bodet. ${ }^{45}$

Febvre immediately began his report together with Paul Rivet, director of the Musée de l'Homme (Museum of Mankind), overriding Huxley's project. Febvre's concept for the History of Mankind focused on "everything that had been subject to circulation," 46 including technical and scientific knowledge, ideas, beliefs, objects, animals, plants, etc. By bringing exchange and circulation to the forefront of the analysis, Febvre designed a narrative where all cultures participate in the building of a common history in a kind of world loan-system, thus avoiding Eurocentrism and evolutionism. The picture that would emerge would be the one of

${ }^{43}$ Cf. Joseph Needham, Chinese Science (London: Pilot Press, 1945); Joseph Needham, ed., Science and Civilisation in China Book Series (Cambridge: Cambridge University Press, 1954-1995). Needham's original project had seven volumes, but it has continued to expand until today, even after his death in 1995. The project is still continuing under the guidance of the Publications Board of the Needham Research Institute and has now 27 volumes (although the original structure of seven volumes was kept, each of them is subdivided in multiple parts).

${ }^{44}$ For a detailed account of the making of the History of Mankind cf. Poul Duedahl, "Selling Mankind: UNESCO and the Invention of Global History, 1945-1976," Journal of World History 22, no. 1 (2011): 101-33.

${ }^{45}$ Huxley did not manage to get the support of the Americans for his reelection as UNESCO directorgeneral.

${ }^{46}$ Duedahl, "Selling Mankind," 110. 
a "humanity in constant motion since its origin through a perpetual series of transcontinental migrations." ${ }^{47}$ In a nutshell, from this standpoint, all civilizations are deeply entangled with each other.

Later in 1949, after a series of awkward events involving Huxley ${ }^{48}$ and a new request from the UNESCO national delegates for a more detailed report, Febvre, Rivet and Needham met for an experts' summit. Febvre and Needham easily found a common ground away from Huxley's Eurocentric and evolutionistic plan: a narrative based on contacts, interchanges, transmission of cultures and knowledge, giving special attention to science and technology as the main hubs for connecting different civilizations.

The Needham-Febvre plan was welcomed at UNESCO's 1950 General Conference, in spite of Huxley's efforts to block it. However, it was the harsh comments of the philosopher Benedetto Croce, the Italian delegate, about the uselessness of the project (on the grounds that it was too expensive and UNESCO's money would be better used to support action in the field) that led to the final decision that UNESCO should not be responsible for writing the History of Mankind, and should hand it over to an independent commission. The composition of this independent commission turned out to be a sort of new round in the dispute staged between Huxley and Febvre, via the American Ralph Turner, from Yale University, and George Morazé from the École des Hautes Études en Sciences Sociales (School for Advanced Studies in the Social Sciences).

After a difficult process of negotiation, Turner's plan, preferred by Huxley, was approved, although with strong criticism concerning the high cost of the budget. As a sort of compensation, Febvre was appointed editor of a new journal created by the commission: the Journal of World History (which also used the French name of Cahiers d'Histoire Mondiale and the Spanish name Cuadernos de Historia Mundial). The Scientific and Cultural History of Mankind was published during the 1960s, presenting a traditional and chronological approach based on the history of the specific contributions of various civilizations to scientific and technological progress. As for the Cahiers, they were launched in 1953 and were quite successful in recovering Febvre's concept for the History of Mankind as a history of mutual influences and exchanges.

\footnotetext{
${ }^{47}$ Ibid., 110.

48 Ibid., 111-12.
} 


\section{Final Remarks}

As historians, let us speak of adaptation to the times. Every period mentally constructs its own universe. It constructs it not only out of all the materials at its disposal, all the facts (true or false) that it has inherited or acquired, but out of its own gifts, its particular cleverness, its qualities, its talents, and its interestseverything that distinguishes it from preceding periods. Similarly, every period mentally constructs its own image of the historical past. ${ }^{49}$

Febvre, Bloch and the Annales are inescapable for any contemporary historian and, by extension, for any historian of science and technology. Their contribution lies deep at the heart of both areas, calling for a common path within history itself. The concept of mentalités, of histoire-probleme and histoire totale hosted a new vision concerning the making of history and its subjects and main players/protagonists. By shifting the axis of analysis from specific events and protagonists (wars, kings, aristocrats) to a longue durée perspective that emphasized the collective nature of mentalities, the Annales reclaimed a huge territory for the realm of history where economy, religion, science, literature, technology, arts, peasants, artisans, servants, merchants, books, mills, instruments, ships, and trains shaped decisions and practices. The history of science and the history of technology found a renewed space within this approach, enlarging their scope and fostering a closer relationship between science, technology and society - science and technology as part of culture and society and as the result of human agency — that still shapes today's narratives.

This critical input was complemented by a closely related second one- -historical temporality. The concepts of "precursor" and "anachronism," which are the basics for any historian of science and technology, are discussed by Febvre in a unique and daring way. Although Febvre's quotation "À chaque civilisation son outillage mental" is the bread and butter of any course in the history of science and technology and repeated over and over again, its amplitude and depth are frequently overlooked. For Febvre and Bloch, these concepts have to do with temporal "thickness," considered by the Annales as a slow-moving fluid, very different from the traditional chronological and linear concept of time in history. This "new" historical time sets the parameters of what is possible or not, that is, forbids anyone from being outside their own time. This approach is not easy to master, as it goes against the common evolutionist perspective that establishes a continuous line towards progress and the popular ideas of geniality and of the visionary, both part of what Febvre called "historique des sciences et des techniques" (historic of science and technology).

The Annales' concept of historical temporality also entails a view of world history that deflects Eurocentrism and the idea of a superior "bright zone," bringing to the stage the relevance of

${ }^{49}$ Febvre, The problem of Unbelief, 2. 
exchanges, circulation, and mutual cross-fertilization of knowledge and practices that are today part of the debate on centers and peripheries, global history and post-colonial studies.

Interdisciplinarity and anti-dogmatism were also an integral part of the Annales rationale: ${ }^{50}$ interdisciplinarity in the sense of both diversifying the lens of analyses and unlocking the well-established disciplinary barriers; anti-dogmatism, as the opposite to positivism and as a way of being free from constraints in order to be able to fully explore all possible questions. The primacy of the question is at the very heart of the histoire-probleme and it is used in a very clear way in most of Bloch's and Febvre's articles, frequently as a way to shift from a traditional approach to a more provocative one. The matter is typically drawn from the present and used to question the past, not as a way to build any chains of justification but to seize the different forms of articulation among layers of analyses and better understand the mechanism of change. This specific back and forth movement between past and present is also one of Annales' most distinctive features.

Designed and consolidated in a difficult period-between the 1929 Great Depression and World War II-the Annales were both a historiographical proposal that embraced global history and rejected determinism, and a project to achieve hegemony within the social sciences. ${ }^{51}$ Led by Bloch and Febvre the Annales fully succeeded in its objectives. During the war, Bloch and Febvre diverged on how to keep the journal and the project alive, but eventually both became a reference in the postwar period. Bloch did not survive the German occupation of France (he was imprisoned by the Gestapo in Montluc prison, tortured and eventually shot on the night of 16 June 1944 in a field near the village of Saint-Didier-de-Formans, in eastern France, together with other Resistance prisoners), but Febvre secured the Annales and trained a new generation that became as influential as the founding one, namely with historians such as Fernand Braudel. In 1953, Febvre published the Combats pour l'histoire, a collection of essays that reinforced the mystique of the Annales.

Febvre's and Bloch's plea to strengthen explicitly the history of science and technology within the mentalités did not find a strong echo or following in the postwar Annales. Only in 1975, that is 40 years after its first issue, Jacques Revel edited the Annales volume on History and Science. ${ }^{52}$ In 1998, that is 63 years after the Annales'special issue on the History of Technology, a new thematic issue on the Histoire des Techniques was published under the coordination of

\footnotetext{
${ }^{50}$ Burguière, "Histoire d'une histoire."

${ }^{51}$ Bloch's Apologie pour l'histoire ou métier d'historien and Febvre's Combats pour l'histoire are particularly strong examples.

52 Jacques Revel, ed., "Histoire et Science," special issue, Annales. Économies, Sociétés, Civilisations 30, no. 5 (1975): 933-1260.
} 
Yves Cohen and Dominique Pestre in the journal Annales. Économies, Sociétés, Civilisations. ${ }^{53}$ However, Febvre's and Bloch's approach to the history of science and technology found other fora to thrive in, mostly within their own disciplinary boundaries. If for historians of science, the Annales' program remained for a long time in the shadow and had to wait for the new trends of contextualism to be (re)discovered-George Sarton's manifesto The New Humanism, published in $1924,{ }^{54}$ focused much more on the relationship between sciences and humanities than on science and society-, for historians of technology it became part of its foundational agenda - the Society for the History of Technology (SHOT) agenda, Melvin Kranzberg's "laws" and the journal Technology and Culture are a clear testimony of this legacy—and was embraced as its paradigm. This asymmetry has undoubtedly to do with the initial objects of the two disciplines: in regards to the history of science, the idea that science is completely distinct from social, political and economic influences had, in the first decades, a strong weight in the community; regarding the history of technology, the weight of materiality—often seen by the history of science as an uninteresting by-product-has always imposed a much more contextualist view, due to the obvious relationship with economy and politics. The celebrated discussion in 1957 between Henry Guerlac, President of the History of Science Society (HSS), and Melvin Kranzberg (member of the HSS and who would soon become the first president of SHOT) about the importance of "thinkers" and "tinkers" as actors in history sums up well the divergent paths traced by both communities. ${ }^{55}$

Regardless of the different paths the history of science and the history of technology took, the Annales are today an influential and unavoidable reference work. The Annales histoire totale, histoire tout court, histoire-probleme, together with the new temporality brought by the longue durée and the global-driven concepts of circulation and exchange of people, ideas, knowledge, practices, animals, and objects (as Febvre said, everything that can move) are today re-appropriated and re-used in the most modern and up-to-date debates and historiographical trends. Undoubtedly Bloch and Febvre, who passionately engaged in the building of a new vision for history, would be thrilled with the success of their project!

53 Yves Cohen and Dominique Pestre, eds., "Histoire des Techniques," special issue, Annales. Économies, Sociétés, Civilisations 53, 4-5 (1998): 721-1071.

${ }^{54}$ George Sarton, “The New Humanism”, Isis 6, no. 1 (1924): 2-42.

55 Robert C. Post, "Back at the Start: History and Technology and Culture," Technology and Culture 51, no. 4 (2010): 961-94 and Robert C. Post, "Chance and Contingency: Putting Mel Kranzberg in Context," Technology and Culture 50, no. 4 (2009): 839-72. 


\section{Competing interests}

The author has declared that no competing interests exist.

\section{Funding}

Maria Paula Diogo thanks the Fundação para a Ciência e a Tecnologia, Portugal, for financial support under project UID/HIS/UI0286/2019 and UIDB/00286/2020. 